\title{
Molluscicidal activity of Ipomoea batatas leaf extracts against Pomacea canaliculata (Golden apple snail)
}

\author{
1,*Noorshilawati, A.A., ${ }^{2}$ Nur Suraya, A. and ${ }^{1}$ Siti Rossiyah, S. \\ ${ }^{1}$ Faculty of Plantation and Agrotechnology, Universiti Teknologi MARA, 26400 Bandar Jengka, Pahang, \\ Malaysia \\ ${ }^{2}$ Faculty of Plantation and Agrotechnology, Universiti Teknologi MARA, 77300 Merlimau, Melaka, \\ Malaysia
}

\section{Article history:}

Received: 22 July 2020

Received in revised form: 4

September 2020

Accepted: 22 December 2020

Available Online: 31

December 2020

\section{Keywords:}

Ipomoea batatas,

Molluscicidal activity,

Mortality rate,

Pomacea canaliculata

DOI:

https://doi.org/10.26656/fr.2017.4(S5).003

\begin{abstract}
This study was conducted to investigate the molluscicidal activity of four different Ipomoea batatas (I. batatas) leaf extracts (hexane, chloroform, methanol, and aqueous extracts) against Pomacea canaliculata ( $P$. canaliculata) and screen the phytochemical compounds of $I$. batatas leaf extracts. The golden apple snails (size range: $20-40 \mathrm{~mm}$ ) were exposed to three concentrations $(1000,5000$, and 10,000 ppm) of each extract (hexane, chloroform, methanol, and aqueous extracts). The efficacy of the I. batatas extracts was laboratory-tested by submerging the $P$. canaliculata into paddy-filled water mixed with the extracts and the mortality was observed every $24 \mathrm{hrs}$ for 3 days. The presence of phytochemical compounds such as terpenoids, flavonoids, saponins, tannins, alkaloids, and glycosides were tested. For all extracts, the results showed a positive relationship between the concentration and the golden apple snail mortality, suggesting that all extracts have molluscicidal properties. The study showed more than $50 \%$ mortality rate of $P$. canaliculata after $72 \mathrm{hrs}$ for each treatment. Chloroform and methanol I. batatas leaf extracts at $10,000 \mathrm{ppm}$ showed $100 \%$ mortality after $72 \mathrm{hrs}$ due to the presence of saponin. Saponin causes the death of the snails by disturbing their feeding and growth and blocking their breathing process. For further research, it is suggested to conduct the study under field trials in the search for a natural and environment-friendly molluscicide.
\end{abstract}

\section{Introduction}

Pomacea canaliculata (P. canaliculata) or also known as golden apple snails has caused severe damage to the paddy industry in Malaysia. The snails were first introduced to South-East Asia in the 1980s for food purposes. Due to low demand, the snail farming was abandoned and the snail escaped to the rice fields (Ruma and Sanchez, 2016). The snail was first found in Malaysia in the 1990s and since then it has become one of the major pests in the paddy industry (Nur Suraya et al., 2017). P. canaliculata attacks and destroys young stems and leaves of plants and could eat 7-24 rice seedlings per day (Cagauan and Joshi, 2002). The damage done by the snails is sufficiently serious and is a major concern. The problem becomes more serious as $P$. canaliculata's populations can increase rapidly under favourable conditions (Ding et al., 2018).

In controlling the infestation of $P$. canaliculata, various methods such as cultural control, biological control, chemical control, salt compounds, organic compounds, and molluscicides have been used (Liang et al., 2013). Handpicking and using ducks are among cultural and biological controls used. These methods have been proven to control the snails at a low cost. However, they require a large labour force and causes damage to the rice seedlings (duck control) (Liang et al., 2013). Chemicals are also widely used in controlling $P$. canaliculata as they are very effective. The principal chemicals used effectively against golden apple snails are metaldehyde, formulated as bait pallets, wettable powders or flowable suspensions, and niclosamide, formulated as either an emulsifiable concentrate, suspension concentrate or wettable powder. Even though they are effective, the use of chemicals is discouraged as they have long-term toxicity effects on humans and the environment. Musman (2010) reported that the usage of chemical fertilisers such as metaldehyde and niclosamide can pollute water sources and thus affect the ecosystem. Furthermore, the cost of chemical molluscicides is unaffordable to many farmers. 
An alternative in organic farming for snail control is by using biopesticides, which are derived from natural compounds such as plants, microorganisms, and minerals. Interest in plant molluscicides has increased in recent years as they have a significant impact (Quijano et al., 2014). Molluscicidal properties have been reported in many plant species. Previous studies have tested and reported the effectiveness of plant extracts in controlling P. canaliculata. Among the plants tested are Solanum mammosum L., Sapindus saponaria L. and Jatropha curcas L. extracts (Quijano et al., 2014), Agave filifera, Ammi majua and Canna indica leaves and flowers (Rawi et al., 2011), and Barringtonia racemosa L. kernel extract (Musman, 2010). The combinations of crude extracts of Sandorium vidalii, Harpulia arborea, and Parkia sp. have also proven to show toxicity towards $P$. canaliculata (Taguiling, 2015).

To date, there is still a continuous effort to search for the most potent organic biological agents that could minimise the invasion and infestation of $P$. canaliculata (Picardal et al., 2018). This study has evaluated the effectiveness of Ipomoea batatas (I. batatas) leaf extracts for their molluscicidal activity against $P$. canaliculata. A screening for phytochemical compounds in the extracts was also conducted.

\section{Materials and method}

\subsection{Preparation of Ipomoea batatas leaf extract}

Four different $I$. batatas leaf extracts (hexane, chloroform, methanol, aqueous) were prepared for this study. Hexane, chloroform, and methanol I. batatas leaf extracts were prepared according to Ayoola et al. (2008). A hundred grams of air-dried leaves were grounded into fine powder and then macerated with $1 \mathrm{~L}$ of solvent (hexane, chloroform, and methanol) for $24 \mathrm{hrs}$ consecutively. The extract was filtered and evaporated using a rotary evaporator. The crude extracts were stored for further use.

For aqueous extraction, the method by Safanah et al. (2012) was adapted. Air-dried leaves were soaked in water for $24 \mathrm{hrs}$, filtered, and centrifuged for $10 \mathrm{mins}$. The extracts then were dried in the oven at $40^{\circ} \mathrm{C}$. The crude extracts were stored for further use. Three different concentrations (1000, 5000, and $10000 \mathrm{ppm}$ ) were prepared for each hexane, chloroform, methanol and aqueous I. batatas leaf extract.

\subsection{Sampling of tested Pomacea canaliculata (golden apple snail)}

The $P$. canaliculata were collected from Integrated Agriculture Development Area (IADA) Pekan, Pahang, the snails were assorted into size class with the size range within 20-40 $\mathrm{mm}$ (Massaguni and Md Latip, 2012). The size of $P$. canaliculata was determined by the height of the shell. The snails were reared for 2-3 days in the laboratory and were fed with papaya leaves (Nur Suraya et al., 2017).

\subsection{Molluscicidal assay test}

The molluscicidal test was adapted from Musman (2010) and Reish and Oshida (1987) with a slight modification. A volume of $1 \mathrm{~L}$ paddy field water was poured into containers holding ten tested snails each. The tested snails were allowed to move freely for about 30 mins before $100 \mathrm{~mL}$ of $I$. batatas extracts were poured into the same containers. The mortality rate was observed every $24 \mathrm{hrs}$ for 3 days. Mucus secretion (Musman, 2010), change in the shell colour and failure of the flesh portion to withdraw into the shell (Abdullahi et al., 2018), and the body hanging out of the shell (Massaguni and Md Latip, 2015) are signs that the snails have died. Three control tests were done where the $P$. canaliculata were treated with paddy field water added with dimethyl sulfoxide (DMSO) and methanol (1:1) (control test for hexane and chloroform extracts), 50\% methanol (control for methanol extract) and distilled water (control for aqueous extract).

\subsection{Phytochemical screening}

Phytochemical screening to determine the presence of alkaloids, flavonoids, glycosides, saponins, tannins, and terpenoids was performed using the methods described by Rauf et al. (2012) and Ayoola et al. (2008). To test for alkaloids, a $0.2 \mathrm{~g}$ sample of the extract was diluted with $2 \% \mathrm{H}_{2} \mathrm{SO}_{4}$ and then added with a few drops of Mayer's reagent. The appearance of a reddish-brown colour indicates the presence of alkaloids. To test for glycosides, a $0.2 \mathrm{~g}$ sample of the extract was hydrolysed with hydrochloric acid $(\mathrm{HCl})$ and then neutralised with sodium hydroxide $(\mathrm{NaOH})$ solution. After that, a few drops of Fehling's A and B solutions were added. A red precipitate is formed if glycoside compounds are present. To test for flavonoids, $\mathrm{NaOH}(1 \mathrm{~mL})$ was added into 0.2 $\mathrm{g}$ extracts and the mixture then was added with a few drops of $\mathrm{HCl}$. The presence of flavonoids is indicated by a change from a yellowish colour to colourless. To test for saponins, a $0.2 \mathrm{~g}$ sample of the extract was added into $2 \mathrm{~mL}$ distilled water in a test tube. The solution was shaken vigorously and observed for stable persistent bubbles. The bubbles' presence indicates the presence of saponins. To test for tannins, a small amount of the extract was diluted using distilled water and heated to boiling point using a water bath. The solution was then filtered and then added with a few drops of ferric 
chloride. The appearance of a dark green colour indicates the presence of tannins. To test for terpenoids, a $0.25 \mathrm{~g}$ sample of the extract was added to $1 \mathrm{~mL}$ of chloroform. Concentrated $\mathrm{H}_{2} \mathrm{SO}_{4}(1.5 \mathrm{~mL})$ was carefully added to form a layer. A reddish-brown colouration of the interface indicates the presence of terpenoids.

\subsection{Lethal concentration $50\left(L C_{50}\right)$}

Lethal concentration $\left(\mathrm{LC}_{50}\right)$ was evaluated by means of Probit Analysis (Finney, 1971). Probit against $\log 10$ concentration was plotted and the concentration to the response ratio was determined.

\section{Results and discussion}

Four different I. batatas leaf extracts (hexane, chloroform, methanol, and aqueous extracts) with three different concentrations were evaluated for their molluscicidal activity against $P$. canaliculata. All extracts showed a positive relationship between the concentration and the golden apple snail mortality, suggesting that all extracts have molluscicidal properties.

Table 1 shows the molluscicidal activity of $I$. batatas leaf hexane extracts against $P$. canaliculata. After being exposed for $24 \mathrm{hrs}$, each concentration only shows between $10-20 \%$ mortality rate. The mortality rate increases with increased exposure time. This is in agreement with Abdullahi et al. (2018) and Musri (2010) who found that the molluscicidal properties of selected plant extracts are time and concentration-dependent. The highest mortality rate of golden apple snail is recorded at $10,000 \mathrm{ppm}$ where the mortality rate is $70 \%$ after $72 \mathrm{hrs}$ exposure. The lowest mortality rate is recorded at the negative control test (20\%) after $72 \mathrm{hrs}$ of exposure. The result indicates that the $I$. batatas hexane leaf extracts have a molluscicidal effect against $P$. canaliculata as shown by the increase in mortality rate with increasing concentration. This result is aligned with the finding by Musman et al. (2013) which showed the decreasing hatchability of $P$. canaliculata eggs with increasing concentration of B. racemosa extracts.

Table 1. Molluscicidal activity of I. batatas leaves hexane extracts $P$. canaliculata

\begin{tabular}{lccc}
\hline \multirow{2}{*}{ Treatment Concentration } & \multicolumn{3}{c}{ Percentage of Mortality (\%) } \\
\cline { 2 - 4 } & $24 \mathrm{hrs}$ & $48 \mathrm{hrs}$ & $72 \mathrm{hrs}$ \\
\hline $1000 \mathrm{ppm}$ & $10^{\mathrm{a}}$ & $20^{\mathrm{a}}$ & $50^{\mathrm{ab}}$ \\
$5000 \mathrm{ppm}$ & $20^{\mathrm{a}}$ & $20^{\mathrm{a}}$ & $60^{\mathrm{ab}}$ \\
$10000 \mathrm{ppm}$ & $20^{\mathrm{a}}$ & $30^{\mathrm{a}}$ & $70^{\mathrm{b}}$ \\
Negative control & $10^{\mathrm{a}}$ & $20^{\mathrm{a}}$ & $20^{\mathrm{a}}$ \\
\hline
\end{tabular}

**Mean followed by the same letter along the column are not significantly difference at $\mathrm{P}>0.05$

I. batatas leaf chloroform extracts show good molluscicidal activity against $P$. canaliculata especially at the $10,000 \mathrm{ppm}$ concentration (Table 2). A previous study by Comia et al. (2018) suggested the same pattern in the result. This may be due to the presence of saponins, tannins, and anthraquinones. All concentrations show $50 \%$ to $100 \%$ mortality rates after being exposed to the treatment for $72 \mathrm{hrs}$. The treatment at a concentration of $1000 \mathrm{ppm}$ has a $50 \%$ mortality rate, while 5000 and 10000 ppm show $70 \%$ and $100 \%$ mortality rates, respectively. For the negative control, a mortality rate of less than $50 \%$ is recorded (after $72 \mathrm{hrs).}$ There is a significant difference in mortality rate between the negative control test and $10,000 \mathrm{ppm}$ treatment concentration test at each recorded time. However, the mortality rate for negative control and $1000 \mathrm{ppm}$ treatment concentration shows no significant difference at the exposures of $24 \mathrm{hrs}, 48 \mathrm{hrs}$ and $72 \mathrm{hrs}$. The varying results reflect the different amounts or types of active compounds present in the different concentrations. The results also reveal the linear relationship between concentration and mortality rate as shown in Figure 1. A similar result was reported by Prabhakaran et al. (2017) who found a linear relationship between the concentrations of six plant extracts (Azadirachta indica, Nicotiana tabacum, Nerium indicum, Pongamia pinnata, Zingiber officinale, and Piper nigrum) and the mortality of Pomacea maculata.

Table 2. Molluscicidal activity of $I$. batatas leaves chloroform extracts against $P$. canaliculata

\begin{tabular}{lccc}
\hline \multirow{2}{*}{ Treatment Concentration } & \multicolumn{3}{c}{ Percentage of Mortality (\%) } \\
\cline { 2 - 4 } & $24 \mathrm{hrs}$ & $48 \mathrm{hrs}$ & $72 \mathrm{hrs}$ \\
\hline $1000 \mathrm{ppm}$ & $20^{\mathrm{a}}$ & $30^{\mathrm{a}}$ & $50^{\mathrm{ab}}$ \\
$5000 \mathrm{ppm}$ & $40^{\mathrm{ab}}$ & $50^{\mathrm{ab}}$ & $70^{\mathrm{b}}$ \\
$10000 \mathrm{ppm}$ & $70^{\mathrm{b}}$ & $90^{\mathrm{b}}$ & $100^{\mathrm{b}}$ \\
Negative control & $10^{\mathrm{a}}$ & $20^{\mathrm{a}}$ & $20^{\mathrm{a}}$ \\
\hline
\end{tabular}

**Mean followed by the same letter along the column are not significantly difference at $\mathrm{P}>0.05$

Based on the result in Table 3, after being exposed to the treatments for $24 \mathrm{hrs}, 30 \%$ of the tested snails show the signs of death. The number of dead snails increases with an increased period of exposure to the treatment. $I$. batatas leaf methanol extracts at $10,000 \mathrm{ppm}$ concentration promise good molluscicidal activity as they take only $48 \mathrm{hrs}$ to show a $100 \%$ mortality rate. The methanol extract of I. batatas leaf extract was found to contain tannins, saponins, and flavonoid that contributed to these results (Anthoney and Omwenga, 2014). Anwar and Przybylski (2012) also found that the use of a polar solvent enables a significant amount of phenolics and flavonoid.

The result of the molluscicidal assay test (Table 4) shows that $I$. batatas leaf aqueous extracts possess good 
Table 3. Molluscicidal activity of $I$. batatas leaves methanol extracts against $P$. canaliculata

\begin{tabular}{lccc}
\hline \multirow{2}{*}{ Treatment Concentration } & \multicolumn{3}{c}{ Percentage of Mortality (\%) } \\
\cline { 2 - 4 } & $24 \mathrm{hrs}$ & $48 \mathrm{hrs}$ & $72 \mathrm{hrs}$ \\
\hline $1000 \mathrm{ppm}$ & $30^{\mathrm{a}}$ & $50^{\mathrm{ab}}$ & $70^{\mathrm{b}}$ \\
$5000 \mathrm{ppm}$ & $30^{\mathrm{a}}$ & $80^{\mathrm{b}}$ & $100^{\mathrm{b}}$ \\
$10000 \mathrm{ppm}$ & $30^{\mathrm{a}}$ & $100^{\mathrm{b}}$ & $100^{\mathrm{b}}$ \\
Negative control & $30^{\mathrm{a}}$ & $30^{\mathrm{a}}$ & $40^{\mathrm{a}}$ \\
\hline
\end{tabular}

**Mean followed by the same letter along the column are not significantly difference at $\mathrm{P}>0.05$

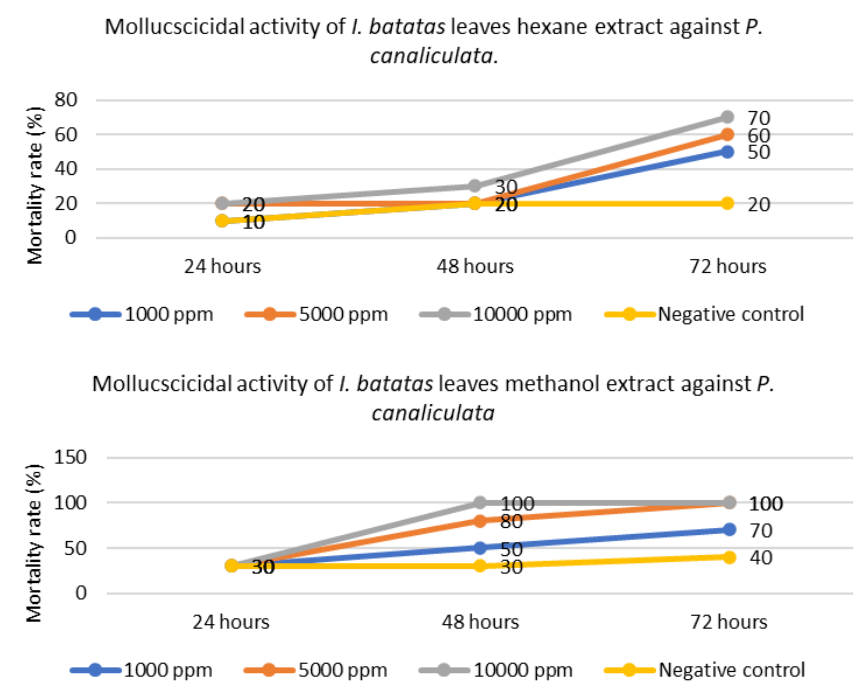

Table 4. Molluscicidal activity of $I$. batatas leaves aqueous extracts against $P$. canaliculata

\begin{tabular}{lccc}
\hline \multirow{2}{*}{ Treatment Concentration } & \multicolumn{3}{c}{ Percentage of Mortality (\%) } \\
\cline { 2 - 4 } & $24 \mathrm{hrs}$ & $48 \mathrm{hrs}$ & $72 \mathrm{hrs}$ \\
\hline $1000 \mathrm{ppm}$ & $0^{\mathrm{a}}$ & $0^{\mathrm{a}}$ & $60^{\mathrm{ab}}$ \\
$5000 \mathrm{ppm}$ & $10^{\mathrm{a}}$ & $30^{\mathrm{a}}$ & $60^{\mathrm{ab}}$ \\
$10000 \mathrm{ppm}$ & $20^{\mathrm{a}}$ & $30^{\mathrm{a}}$ & $70^{\mathrm{b}}$ \\
Negative control & $0^{\mathrm{a}}$ & $0^{\mathrm{a}}$ & $30^{\mathrm{a}}$ \\
\hline
\end{tabular}

**Mean followed by the same letter along the column are not significantly difference at $\mathrm{P}>0.05$

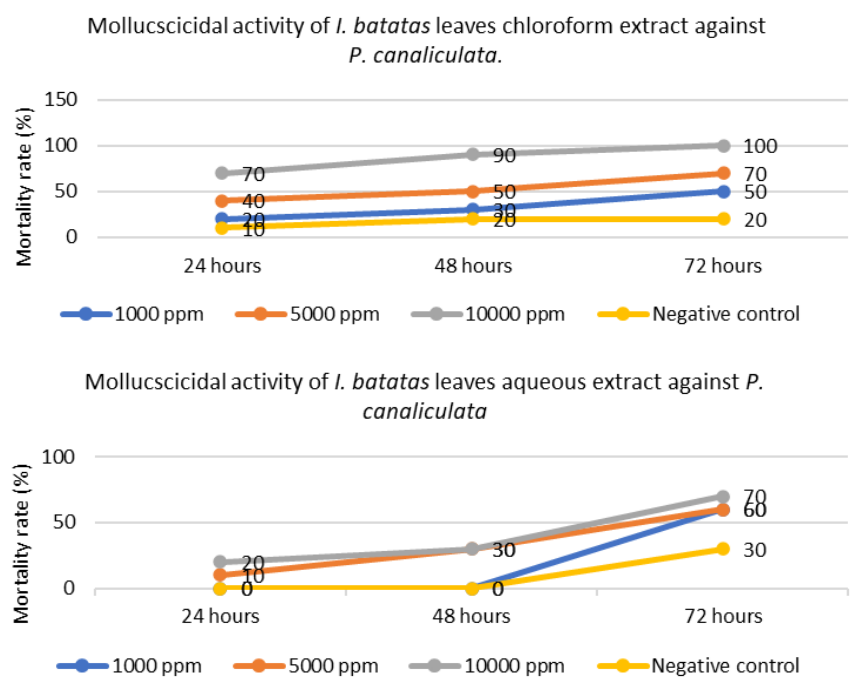

Figure 1. Molluscicidal activity of different $I$. batatas leaves extracts (hexane, chloroform, methanol and aqueous) against $P$. canaliculata

molluscicidal activity as more than $50 \%$ mortality rate is observed for each treatment after 72 hrs. The mortality rates recorded after $72 \mathrm{hrs}$ of exposure are $60 \%(1000$ ppm), 60\% (5000 ppm), 70\% (10,000 ppm), and 30\% (negative control). For negative control, there is no mortality rate recorded for the first $(24 \mathrm{hrs})$ and second (48 hrs) readings. However, a $30 \%$ mortality rate is recorded after $72 \mathrm{hrs}$. A previous study by Liang et al. (2013) proved that the deaths are caused by environmental stress. An environment of stagnant water and warmer temperature can result in stress in the tested snails.

Plants are believed to have been commercialised as biopesticides because they contain various secondary metabolites that show superior anti-pest activities (Noorshilawati et al., 2015). I. batatas have been proven to show a broad spectrum of larvicidal activity (Bharathi et al., 2017). The phytochemical screening indicated that I. batatas leaf extract contains active compounds like flavonoids, saponins, tannins, and terpenoids (Table 5) which play an important role in controlling the snails' population (Noorshilawati et al., 2018). This finding is in agreement with the finding by Picardal et al. (2018).

Flavonoids and saponins found in I. batatas may act synergistically in controlling $P$. canaliculata (Comia et al., 2018). A study by Koncic et al. (2013) also found a significant amount of phenols and flavonoids which can increase the rate of saponin absorption into the snail's hepatic cells and thus lead to death. Souza et al. (2013) revealed that flavonoids can inhibit the snail's detoxification system and allow saponins to induce greater toxicity. Saponins demonstrate the molluscicidal activity by disturbing the feeding and growth of the pest. The finding by Musman (2010) also support the molluscicidal effect of flavonoids and saponins where the mortality rate of the tested $P$. canaliculata is higher in extracts containing both flavonoids and saponins compared to the extracts containing only flavonoids. Taguiling (2015) also found that saponins exhibit pesticidal activity. Saponins also could lower the surface tension of water and block the breathing process (Musman, 2010).

Table 5. Phytochemical screening result

\begin{tabular}{cc}
\hline Phytochemical Test & Result \\
\hline Alkaloids & Negative (-) \\
Flavonoids & Positive (+) \\
Glycosides & Negative (-) \\
Saponins & Positive (+) \\
Tannins & Positive (+) \\
Terpenoids & Positive (+) \\
\hline
\end{tabular}

(C) 2020 The Authors. Published by Rynnye Lyan Resources 
LC50: Grapical method (hexane)

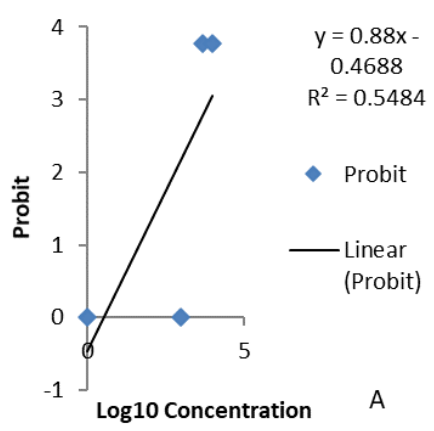

LC50: Grapical method (methanol)

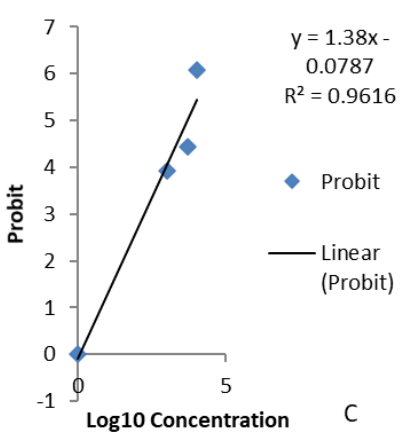

LC50: Grapical method (chloroform)

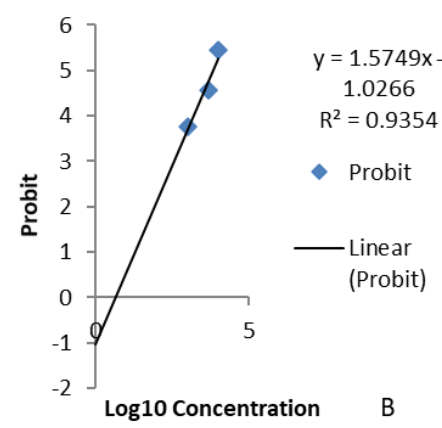

LC50: Graphical method (aqueous)

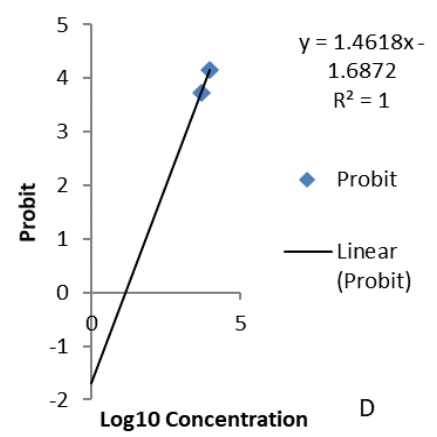

Figure 2. Lethal concentration $\left(\mathrm{LC}_{50}\right)$ of different $I$. batatas leaves extracts

Meanwhile, the presence of tannins in the phytochemical screening shows a direct toxicity effect that leads to the mortality rate of $P$. canaliculata. Tannins are endogenous inhibitors of growth for numerous species of pests. Besides being good for pesticidal activity, tannins also can be used as bactericides ( $\mathrm{Vu}$ et al., 2017). Terpenoids screened in $I$. batatas leaf extracts also play an important role in plant defence against pests. Terpenoids' toxicity is by acting as an antifeedant and growth disruptor (Castilhos et al., 2017).

Based on the probit analysis of $\mathrm{LC}_{50}$ (Figure 2), to control $50 \%$ of the golden apple snail population, about 1639 ppm Ipomoea batatas leaf hexane extracts are suggested for application. While the suggested concentration for Ipomoea batatas leaf chloroform, methanol, and aqueous extracts are about 6709 ppm, $4789 \mathrm{ppm}$, and $37549 \mathrm{ppm}$, respectively (Table 6).

Table 6. Lethal concentration 50 value of Ipomoea batatas leaves extracts with $95 \%$ confidence interval

\begin{tabular}{lc}
\hline Extracts & Suggested Concentration \\
\hline Hexane & $1639 \mathrm{ppm}$ \\
Chloroform & $6709 \mathrm{ppm}$ \\
Methanol & $4789 \mathrm{ppm}$ \\
Aqueous & $37549 \mathrm{ppm}$ \\
\hline
\end{tabular}

\section{Conclusion}

I. batatas leaf extracts have potency in controlling golden apple snails especially I. batatas methanol leaf extracts and can be used as alternative molluscicides. Therefore, the use of I. batatas extracts as molluscicides are highly recommended because they are environmentally safe, toxicological friendly, easy to use, and have a wide range of insecticidal activity. In addition, it is suggested that this study should be conducted on the paddy field to investigate the environmental effect caused by the I. batatas leaf extracts.

\section{Conflict of interest}

The authors hereby declare no conflict of interest.

\section{Acknowledgements}

The authors would like to express our gratitude to the Plant Pathology Laboratory Staff of Universiti Teknologi MARA Pahang for their help to complete this research work. The authors also wish to acknowledge the Ministry of Higher Education (MOHE) for its funding through the Fundamental Research Grant Scheme (FRGS/1/2016/ WAB01/UITM/03/2).

\section{References}

Abdullahi, Y., Muhammad, I. and Yerima, M. (2018). Molluscicidal activity of aqueous extract of leaves, stem back and roots of desert date (Balanite egyptiaca Del.) against common liver fluke (Fasciola hepatica) found in the snail (Lymnea 
natalensis). Journal of Applied Sciences and Environmental Management, 22(3), 409-413. https:// doi.org/10.4314/jasem.v22i3.21

Anthoney, S.T. and Omwenga, J. (2014). Analysis of phythochemical composition of white and purple sweet potato (Ipomoea batatas [L. Lam) root. Indian Journal of Advances in Plant Research, 1, 19-22.

Anwar, F. and Przybylski, R. (2012). Effect of solvents extraction on total phenolic and antioxidant activity of extracts from flaxseed (Linum usitatissimum L.). Acta scientiarum polonorum. Technologia alimentaria, 11(3), 293-301.

Ayoola, G.A., Coker, H.A.B., Adesegun, S.A., AdepojuBello, A.A., Obaweya, K., Ezennia, E.C. and Atangbayaila, T.O. (2008). Phytochemical screening and antioxidant activities of some selected medicinal plants used for malaria therapy in Southwestern Nigeria. Tropical Journal of Pharmaceutical Research, 7(3), 1019-1024. https://doi.org/10.4314/ tjpr.v7i3.14686

Bharathi, V.P., Ragavendran, C., Murugan, N. and Natarajan, D. (2017). Ipomoea batatas (Convolvulaceae)-mediated synthesis of silver nanoparticles for controlling mosquito vectors of Aedes albopictus, Anopheles stephensi and Culex quinquefasciatus (Diptera: Culicidae). Artificial Cells, Nanomedicine, and Biotechnology, 45(8), 1568-1580.

doi.org/10.1080/21691401.2016.1261873

Cagauan, A.G. and Joshi, R.C. (2002). Predation of freshwater fish on golden apple snail, Pomacea canaliculata Lam., under screenhouse conditions. International Rice Research Notes, 27(2), 24-26.

Castilhos, R.V., Grützmacher, A.D. and Coats, J.R. (2017). Acute toxicity and sublethal effects of terpenoids and essential oils on the predator Chrysoperla externa (Neuroptera: Chrysopidae). Neotropical Entomology, 47(2), 311317. https://doi.org/10.1007/s13744-017-0547-6

Comia, C.V.B., Datinguinoo, H.D., Magadia, S.A.S., Manalo, R.G., Manigbas, A.J.P., MagbojosMagtibay, C.R. and De Villa, L.M.C (2018). Molluscicidal effects of Bambusa blumeana (bamboo) leaf extracts against the adult stage of the snail vector model Pomacea canaliculata. The STETH, 12, 90-115.

Ding, W., Huang, R., Zhou, Z., Hea, H. and Lia, Y. (2018). Ambrosia artemisiifolia as a potential resource for management of golden apple snails, Pomacea canaliculata (Lamarck). Pest Management Science, 74(A), 944-949. https://doi.org/10.1002/ ps.4792
Koncic, M.Z., Petlevski, R. and Kalođera, Z. (2013). Antioxidant activity of Ipomoea batatas 1. lam. Leaf grown in continental Croatia and its effect on glutathione level in glucose-induced oxidative stress. International Journal of Food Properties, 16(5), 964 -973. https://doi.org/10.1080/10942912.2011.573117

Liang, K., Zhang, J., Fang, L., Zhao, B., Luo, M., Parajuli, P. and Ouyang, Y. (2013). The biological control of Pomacea canaliculata population by riceduck mutualism in paddy fields. Biocontrol Science and Technology, 23(6), 674-690. https:// doi.org/10.1080/09583157.2013.790933

Massaguni, R. and Md Latip, S.N.H. (2015). Assessment the molluscicidal properties of Azadirachtin against golden apple snail (Pomacea canaliculata). Malaysian Journal of Analytical Sciences, 19(4), 781 $-789$.

Massaguni, R. and Md Latip, S.N.H., (2012). Neem crude extract as potential biopesticide for controlling golden apple snail, Pomacea canaliculata. In Soundararajn, R.P. (Ed.) Pesticides - Advances in Chemical and Botanical Pesticides, p. 234-251. IntechOpen E-Book.https://doi.org/10.5772/48626

Musman, M. (2010). Toxicity of Barringtonia racemosa (L.) kernel extract on Pomacea canaliculata (Ampullariidae). Tropical Life Sciences Research, 21 (2), $41-50$.

Musman, M., Kamaruzzaman, S., Karina, S., Rizqi, R. and Arisca, F. (2013). A preliminary study on the anti-hatching of freshwater golden apple snail Pomacea canaliculata (Gastropoda: Ampullariidae) eggs from Barringtonia racemosa (Magnoliopsida: Lecythidaceae) seeds extract. International Journal of the Bioflux Society, 6(4), 394-398.

Noorshilawati, A.A., Nur Suraya, A. and Norhana, A. (2018). Larvicidal effects of Murraya koenigii extracts against the larvae of Metisa plana. GADING Journal for Science and Technology, 1(1), 71 - 79.

Noorshilawati, A.A., Umi Nadhirah, H. and Nur Suraya, A. (2015). Phytochemical screening and in vitro antibacterial activity of Elaeis guineensis leaves extracts against human pathogenic bacteria. Malaysian Journal of Analytical Sciences, 19(4), 775 -780 .

Nur Suraya, A., Noorshilawati, A.A. and Rosminah, M. (2017). Molluscicidal activity of Entada rheedii stem bark methanolic extract against paddy pest Pomacea canaliculata (golden apple snail). Malaysian Journal of Analytical Sciences, 21(1), 46-51. https:// doi.org/10.17576/mjas-2017-2101-06

Picardal, M.T., Panlaan, K.T., Castaño, P.M.L., Peña, L.G., Abella, K.T. and Picardal, J.P. (2018). 
Molluscicidal activity of the aqueous extract of garlic (Allium sativum L.) bulb against golden apple snail (Pomacea canaliculata L.). International Journal of Biosciences, 13(2), 75-87.

Prabhakaran, G., Bhore, S.J. and Ravichandran, M. (2017). Development and evaluation of poly herbal molluscicidal extracts for control of apple snail (Pomacea maculata). Agriculture, 7(3), 22. https:// doi.org/10.3390/agriculture7030022

Quijano, M., Riera-Ruíz, C., Barragán, A., Miranda, M., Orellana, T. and Manzano, P. (2014). Molluscicidal activity of the aqueous extracts from Solanum mammosum L., Sapindus saponaria L. and Jatropha curcas L. against Pomacea canaliculata. Emirates Journal of Food and Agriculture, 26(10), 871-877. https://doi.org/10.9755/ejfa.v26i10.18804

Rauf, A., Qaisar, M., Uddin, G., Akhtar, S. and Muhammad, N. (2012). Preliminary phytochemical screening and antioxidant profile of Euphorbia prostrate. Middle-East Journal of Medicinal Plants Research, 1(1), 9-13.

Rawi, S.M., Al-Hazmi, M. and Seif Al Nassr, F. (2011). Comparative study of the molluscicidal activity of some plant extracts on the snail vector of Schistosoma mansoni, Biomphalaria alexandrina. International Journal of Zoological Research, 7(2), 169-189. https://doi.org/10.3923/ijzr.2011.169.189

Reish, D.L. and Oshida, P.S. (1987). Manual of methods in aquatic environment research. Part 10: Shorterm static bioassay. FAO Fisheries Technical Paper 247. Food and Agriculture Organization of the United Nations. p. 81. Rome: FAO.

Ruma, O.C. and Sanchez, N.M. (2016). Ethanolic leaf extract of Jatropha curcas L. as golden apple snail (Pomaceae canaliculata Lam.) Repellent. Tropical Agriculture and Development, 60(4), 286-290.

Safanah, A.F., Mohammed, F., Hadi, H.A. and Abdul, K.M.N.J. (2012). Study of some Urtica dioica L. Leaves components and effect of their extracts on growth of pathogenic bacteria and identify of some flavonoids by HPLC. Al-Mustansiriya Journal of Science, 23(3), 79-86.

Souza, B.A., da Silva, L.C., Chicarino, E.D. and Bessa, E.C.A. (2013). Preliminary phytochemical screening and molluscicidal activity of the aqueous extract of Bidens pilosa Linne (Asteraceae) in Subulina octona (Mollusca, Subulinidade). Anais da Academia Brasileira de Ciências, 85(4), 1557-66. https:// doi.org/10.1590/0001-37652013111812

Taguiling, N.K. (2015). Effect of combined plant extracts on golden apple snail (Pomacea canaliculata (Lam.)) and giant earthworm
(Pheretima sp). International Journal of Agriculture and Crop Sciences, 8(1), 55-60.

Vu, T.T., Kim, H., Tran, V.K., Vu, H.D., Hoang, T.X., Han, J.W., Choi, Y.H., Jang, K.S., Choi, G.J. and Kim, J.C. (2017). Antibacterial activity of tannins isolated from Sapium baccatum extract and use for control of tomato bacterial wilt. PLoS ONE, 12(7), e0181499. journal.pone.0181499 